UNITED STATES DEPARTMENT OF THE INTERIOR

GEOLOGICAL SURVEY

\title{
Analytical results and sample locality map \\ of stream-sediment, heavy-mineral-concentrate, and rock samples \\ from the Sierra Estrella Wilderness Study Area, \\ Maricopa County, Arizona
}

By

S.C. Rose ${ }^{\star}$, B.M. Adrian ${ }^{\star}$, P.H. Briggs ${ }^{\star}$,

and R.J. Goldf arb ${ }^{\star}$

Open-File Report 89-17

This report is preliminary and has not been reviewed for conformity with U.S. Geological Survey editorial standards and stratigraphic nomenclature. Any use of trade names is for descriptive purposes only and does not imply endorsement by the USGS.

*U.S. Geological Survey, DFC, Box 25046, MS 973, Denver, CO 80225 


\section{CONTENTS}

Studies Related to Wilderness............................... 1

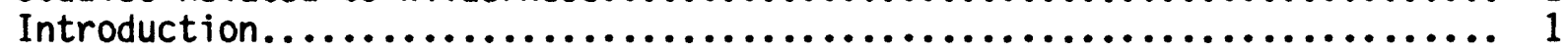

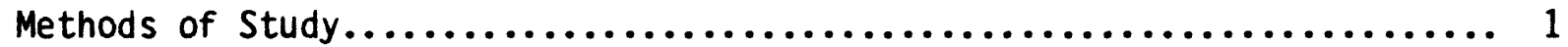

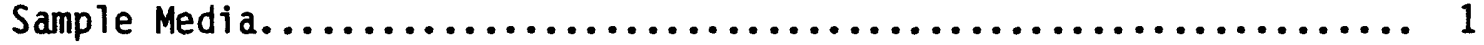

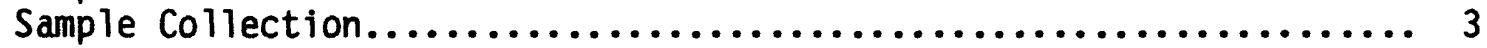

Stream-sediment samples........................... 3

Heavy-mineral-concentrate samples...................... 3

Rock samples................................... 3

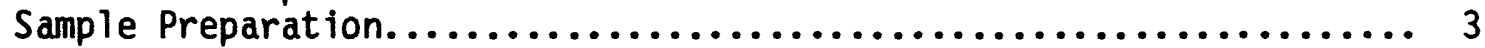

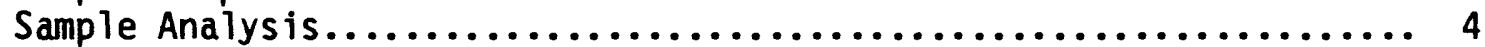

Spectrographic method........................... 4

Chemical methods.................................. 4

Data Storage System ..................................... 4

Description of Data Tables.............................. 4

References Cited...................................... 5

\section{ILLUSTRATIONS}

Figure 1. Location map of the Sierra Estrella Wilderness Study Area,

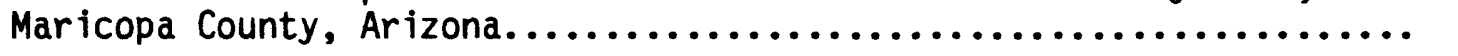

Plate 1. Localities of heavy-mineral-concentrate, stream-sediment, and rock samples from the Sierra Estrella Wilderness Study Area,

Maricopa County, Arizona............................ in pocket

\section{TABLES}

Table 1. Limits of determination for spectrographic analysis of

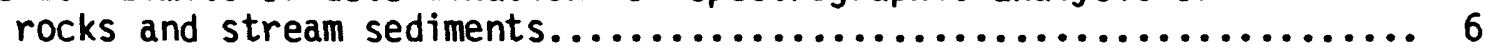

Table 2. Chemical methods used........................... 7

Table 3. Results of analyses of stream-sediment samples............ 8

Table 4. Results of analyses of heavy-mineral-concentrate samples...... 11

Table 5. Results of analyses of rock samples.................. 13

Table 6. Description of rock samples........................ 13 


\section{STUDIES RELATED TO WILDERNESS}

\section{Bureau of Land Management Wilderness Study Areas}

The Federal Land Policy and Management Act (Public Law 94-579, October 21, 1976) requires the U.S. Geological Survey and the U.S. Bureau of Mines to conduct mineral surveys on certain areas to determine their mineral values, if any. Results must be made available to the public and be submitted to the President and the Congress. This report presents the results of a geochemical survey of the Sierra Estrella Wilderness Study Area, Maricopa County, Arizona.

\section{INTRODUCTION}

In October 1987, the U.S. Geological Survey conducted a reconnaissance geochemical survey of the Sierra Estrella Wilderness Study Area (WSA), Maricopa County, Arizona (AZ-020-160).

The Sierra Estrella WSA comprises about $22 \mathrm{mi}^{2}\left(58 \mathrm{~km}^{2}\right)(14,190$ acres) in Maricopa County, Arizona, and lies roughly $15 \mathrm{mi}(24 \mathrm{~km})$ southwest of Phoenix, Arizona. Access to the study area is provided by numerous gravel roads extending eastward from a paved road which intersects State Highway 85 near Liberty, Arizona (see fig. 1). Topographic relief ranges from roughly 4,100 $\mathrm{ft}$ in the eastern part of the study area to $1,400 \mathrm{ft}$ in the west. The study area is characterized by steep rugged mountains of the Sierra Estrella Range with fringing pediments to the southwest.

The Sierra Estrella WSA is underlain by foliated schists and gneisses of Precambrian age which have been locally intruded by Precambrian granite and pegmatite dikes. The northern part of the WSA is cut by Tertiary (?) mafic dikes (Spencer et al., 1985). Several small pegmatite bodies have been exploited for mica (Korzeb, 1988), and a number of placer gold claims are located in the pediments near the west boundary of the WSA.

\section{METHODS OF STUDY}

\section{Sample Media}

Analyses of the stream-sediment samples represent the chemistry of the rock material eroded from the drainage bas in upstream from each sample site. Such information is useful in identifying those basins which contain concentrations of elements that may be related to mineral deposits. Heavy-mineral-concentrate samples provide information about the chemistry of certain minerals in rock material eroded from the drainage bas in upstream from each sample site. The selective concentration of minerals, many of which may be ore related, permits determination of some elements that are not easily detected in stream-sediment samples.

Analyses of unaltered or unmineralized rock samples provide background geochemical data for individual rock units. On the other hand, analyses of altered or mineralized rocks, where present, may provide useful geochemical information about the major- and trace-element assemblages associated with a mineralizing system. 


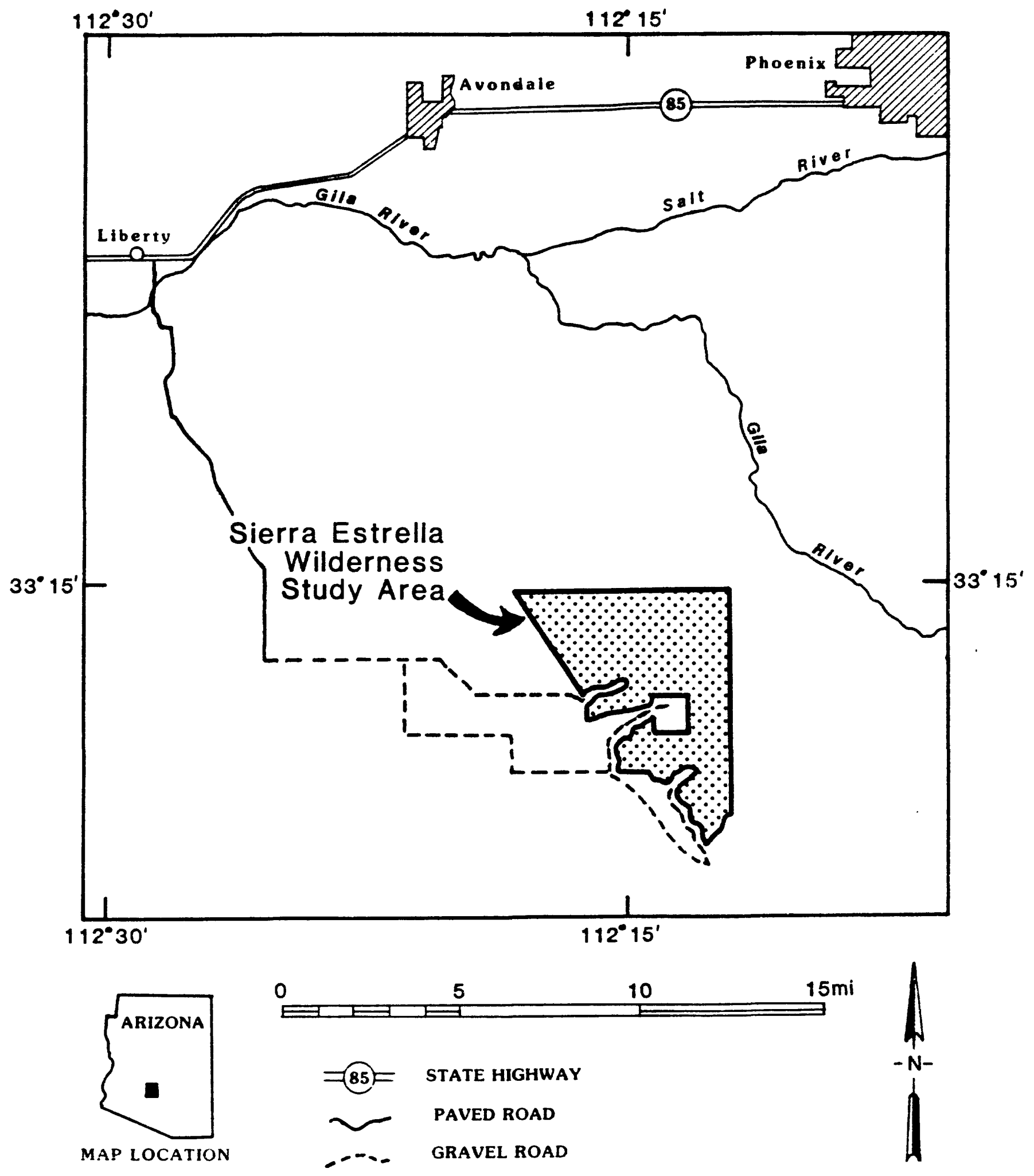

Figure 1. Location map of the Sierra Estrella Wilderness Study Area, Maricopa County, Arizona (modified from Korzeb, 1988). 


\section{Sample Collection}

Samples were collected at 26 sites ( $p$ late 1 ). Both a stream-sediment sample and a heavy-mineral-concentrate sample were collected at all sites. Where suitable outcrop was available, rock samples werg collected. Average sampling density was about one sample site per $0.85 \mathrm{mi}^{2}$ for the stream sediments and heavy-mineral concentrates. The area of the drainage basins sampled ranged from $0.3 \mathrm{mi}^{2}$ to $2.5 \mathrm{mi}^{2}$.

\section{Stream-sediment samples}

The stream-sediment samples consisted of active alluvium collected primarily from first-order (unbranched) and second-order (below the junction of two first-order) streams as shown on USGS topographic maps (scale = $1: 24,000)$. Each sample was composited from several localities within an area that may extend as much as $20 \mathrm{ft}$ from the site plotted on the map.

\section{Heavy-minera1-concentrate samples}

Heavy-mineral-concentrate samples were collected from the same active alluvium as the stream-sediment samples. Each bulk sample was screened with a 2.0-mm (10-mesh) screen to remove the coarse material. The less than 2.0-mm fraction was panned until most of the quartz, feldspar, organic material, and clay-sized material were removed.

\section{Rock samples}

Rock samples were collected from various types of occurrences in the vicinity of the plotted site location. Descriptions of rock samples are in table 6 .

\section{Sample Preparation}

The stream-sediment samples were air dried, then sieved using 80-mesh $(0.17-\mathrm{mm})$ stainless-steel sieves. The portion of the sediment passing through the sieve was saved for analysis.

After air drying, bromoform (specific gravity 2.8) was used to remove the remaining quartz and feldspar from the heavy-mineral-concentrate samples that had been panned in the field. The resultant heavy-mineral sample was separated into three fractions using a large electromagnet (in this case a modified Frantz Isodynamic Separator). The most magnetic material, primarily magnetite, was not analyzed. The second fraction, largely ferromagnesian silicates and iron oxides, was saved for archival storage. The third fraction (the least magnetic material which may include the nonmagnetic ore minerals, zircon, sphene, etc.) was split using a Jones splitter. One split was hand ground for spectrographic analysis; the other split was saved for mineralogical analysis. These magnetic separates are the same separates that would be produced by using a Frantz Isodynamic Separator set at a slope of $15^{\circ}$ and a tilt of $10^{\circ}$ with a current of 0.2 ampere to remove the magnetite and ilmenite, and a current of 0.6 ampere to split the remainder of the sample into paramagnetic and nonmagnetic fractions.

Rock samples were crushed and then pulverized to minus $0.15 \mathrm{~mm}$ with ceramic plates. 


\section{Sample Analysis}

\section{Spectrographic method}

The stream-sediment, heavy-mineral-concentrate, and rock samples were analyzed for 35 elements using a semiquantitative, direct-current arc emission spectrographic method (Grimes and Marranzino 1968). The elements analyzed and their lower limits of determination are listed in table 1. Spectrographic results were obtained by visual comparison of spectra derived from the sample against spectra obtained from standards made from pure oxides and carbonates. Standard concentrations are geometrically spaced over any given order of magnitude of concentration as follows: 100,50,20,10, and so forth. Samples whose concentrations are estimated to fall between those values are assigned values of $70,30,15$, and so forth. The precision of the analytical method is approximately plus or minus one reporting interval at the 83 percent confidence level and plus or minus two reporting intervals at the 96 percent confidence level (Motooka and Grimes, 1976). Values determined for the major elements, iron, magnesium, calcium, and titanium, are given in weight percent; all others are given in parts per million (micrograms/gram). Analytical data for samples from the Sierra Estrella WSA are 1isted in tables 3,4 , and 5 .

\section{Chemical methods}

Samples from this study area were also analyzed by other analytical methods. Rocks and stream sediments were analyzed for gold (Au) using flameless atomic absorption spectroscopy, and for arsenic (As), bismuth (Bi), cadmium (Cd), and zinc ( $\mathrm{Zn})$ using inductively coupled plasma-atomic emission spectroscopy (ICP). Selected rocks were analyzed for gold using atomic absorption spectroscopy. See table 2 for a more detailed summary of these other chemical methods used. Analytical results for stream-sediment, heavyminera 1-concentrate, and rock samples are listed in tables 3, 4, and 5, respectively.

\section{DATA STORAGE SYSTEM}

Upon completion of all analytical work, the analytical results were entered into either the Branch of Geochemistry computer base called PLUTO or RASS (Rock Analysis Storage System). These data bases contain both descriptive geological information and analytical data. Any or all of this information may be retrieved and converted to a binary form (STATPAC) for computerized statistical analysis or publication (VanTrump and Miesch, 1977).

\section{DESCRIPTION OF DATA TABLES}

Tables 3-5 list the results of analyses for the samples of stream sediment, heavy-mineral concentrate, and rock, respectively. For the three tables, the data are arranged so that column 1 contains the USGS-assigned sample numbers. These numbers correspond to the numbers shown on the site location map ( $p$ late 1). Columns in which the element headings show the letter "s" below the element symbol are emission spectrographic analyses, and "icp" indicates inductively coupled plasma-atomic emission spectroscopy. A letter "N" in the tables indicates that a given element was looked for but not detected at the lower limit of determination shown for that element in 
table 1. For emission spectrographic analyses, a "less than" symbol (<) entered in the tables in front of the lower limit of determination indicates that an element was observed but was below the lowest reporting value. For ICP analyses, a "less than" symbol (<) entered in the tables in front of the lower limit of determination indicates that an element was below the lowest reporting value. If an element was observed but was above the highest reporting value, a "greater than" symbol ( $>$ ) was entered in the tables in front of the upper limit of determination. Because of the formatting used in the computer program that produced tables 3-5, some of the elements listed in these tables ( $\mathrm{Fe}, \mathrm{Mg}, \mathrm{Ca}, \mathrm{Ti}, \mathrm{Ag}$, and $\mathrm{Be}$ ) carry one or more nonsignificant digits to the right of the significant digits. The analysts did not determine these elements to the accuracy suggested by the extra zeros.

The spectrographic determinations for $\mathrm{As}, \mathrm{Au}, \mathrm{Bi}, \mathrm{Cd}, \mathrm{Mo}, \mathrm{Sb}, \mathrm{W}, \mathrm{Zn}$, Th, and $\mathrm{Ge}$ in stream-sediment samples; for $\mathrm{Ag}, \mathrm{As}, \mathrm{Au}, \mathrm{Bi} \mathrm{Cd}, \mathrm{Ge}, \mathrm{Ni}, \mathrm{Sb}, \mathrm{Pd}$, and $\mathrm{Pt}$ in heavy-mineral-concentrate samples; and for $\mathrm{As}, \mathrm{Au}, \mathrm{Cd}, \mathrm{Mo}, \mathrm{Nb}, \mathrm{Sb}, \mathrm{W}$, $\mathrm{Zn}$, Th, Ge, and $\mathrm{P}$ in rock samples were all below the lower limits of determinations shown in table 1 . Consequently, the columns for these elements have been deleted from tables 3,4 , and 5 , respectively. All of the spectrographic determinations for $Z r$ in heavy-mineral-concentrate samples were al1 above the upper limit of determination shown in table 1 , and therefore $\mathrm{Zr}$ was omitted from table 4. Stream-sediment samples were analyzed for gold by the atomic absorption method described by Thompson et a1. (1968). No detectable amounts were found; consequently Au was omitted from table 3.

\section{REFERENCES CITED}

Crock, J.G., Briggs, P.H., Jackson, L.L., and Lichte, F.E., 1987, Analytical methods for the analysis of stream sediments and rocks from wilderness study areas: U.S. Geological Survey Open-File Report 87-084, p. 1-35.

Grimes, D.J., and Marranzino, A.P., 1968, Direct-current arc and alternatingcurrent spark emission spectrographic field methods for the semiquantitative analys is of geologic materials: U.S. Geological Survey Circular 591, $6 \mathrm{p}$.

Korzeb, E.L., 1988, Mineral investigation of the Sierra Estrella Wilderness Study Area (AZ-020-160), Maricopa County, Arizona: U.S. Bureau of Mines Open-File Report MLA 7-88, 12 p.

Motooka, J.M., and Grimes, D.J., 1976, Analytical precision of one-sixth order semiquantitative spectrographic analyses: U.S. Geological Survey Circular 738, 25 p.

Spencer, J.E., Reynolds, S.J., Anderson, P., and Anderson, J.L., 1985, Reconnaissance geology of the crest of the Sierra Estrella, central Arizona: Arizona Bureau of Geology and Mineral Technology Open-File Report 85-11, $20 \mathrm{p}$.

Thompson, C.E., Nakagawa, H.M., and Van Sickle, G.H., 1968, Rapid analysis for gold in geologic materials, in Geological Survey research 1968: U.S. Geological Survey Professional Paper 600-B, p. B130-B132.

VanTrump, George, Jr., and Miesch, A.T., 1977, The U.S. Geological Survey RASS-STATPAC system for management and statistical reduction of geochemical data: Computers and Geosciences, v. 3, p. 475-488. 
TABLE 1.--Limits of determination for the spectrographic analysis of rocks and stream sediments, based on a 10-mg sample

[The spectrographic limits of determination for heavy-minera]-concentrate samples are based on a 5-mg sample, and are therefore two reporting intervals higher than the limits given for rocks and stream sediments]

Elements Lower determination limit Upper determination limit

Percent

\begin{tabular}{lcc}
\hline Iron (Fe) & 0.05 & 20 \\
Magnesium $(\mathrm{Mg})$ & .02 & 10 \\
Calcium (Ca) & .05 & 20 \\
Titanium (Ti) & .002 & 1 \\
Sodium (Na) & .2 & 5 \\
Phosphorus (P) & .2 & 10 \\
\hline
\end{tabular}

Parts per million

\begin{tabular}{lrr}
\hline Manganese (Mn) & 10 & 5,000 \\
Silver (Ag) & 0.5 & 5,000 \\
Arsenic (As) & 200 & 10,000 \\
Gold (Au) & 10 & 500 \\
Boron (B) & 10 & 2,000 \\
Barium (Ba) & 20 & 5,000 \\
Beryllium (Be) & 1 & 1,000 \\
Bismuth (Bi) & 10 & 1,000 \\
Cadmium (Cd) & 20 & 500 \\
Cobalt (Co) & 5 & 2,000 \\
Chromium (Cr) & 10 & 5,000 \\
Copper (Cu) & 5 & 20,000 \\
Lanthanum (La) & 20 & 1,000 \\
Molybdenum (Mo) & 5 & 2,000 \\
Niobium (Nb) & 20 & 2,000 \\
Nickel (Ni) & 5 & 5,000 \\
Lead (Pb) & 10 & 20,000 \\
Antimony (Sb) & 100 & 10,000 \\
Scandium (Sc) & 5 & 100 \\
Tin (Sn) & 10 & 1,000 \\
Strontium (Sr) & 100 & 5,000 \\
Vanadium (V) & 10 & 10,000 \\
Tungsten (W) & 50 & 10,000 \\
Yttrium (Y) & 10 & 2,000 \\
Zinc (Zn) & 200 & 10,000 \\
Zirconium (Zr) & 10 & 1,000 \\
Thorium (Th) & 100 & 2,000 \\
Gallium (Ga) & 5 & 500 \\
Germanium (Ge) & 50 & 100 \\
Palladium (Pd) & & 500 \\
Platinum (Pt) & 50 & 500 \\
\hline & & \\
\hline
\end{tabular}


TABLE 2.--Commonly used chemical methods

[AA = atomic absorption; $I C P=$ induct ively coupled plasma spectroscopy $]$

Element or constituent determined

\begin{tabular}{llcc}
\hline Gold (Au) & AA & 0.05 & $\begin{array}{c}\text { Thompson and } \\
\text { others, 1968. }\end{array}$ \\
Arsenic (As) & ICP & 5 & Crock and others, 1987. \\
Zinc (Zn) & ICP & 2 & \\
Bismuth (Bi) & ICP & 2.1 & \\
Cadmium (Cd) & ICP & .1 & \\
\hline
\end{tabular}


TABLE 3--ANALYSES OF MINUS-80-MESH ST'REAM SEDIMENT SAMPLES FROM THE SIERRA ESTRELLA WILDERNESS STUDY AREA, MARICOPA COUNTY, ARIZONA.

( $N$, not detected; <, detected but below the limit of determination shown; >, determined to be greater than the value shown.)

\begin{tabular}{|c|c|c|c|c|c|c|c|c|c|c|c|}
\hline Sample & Lat i tude & Longi tude & $\begin{array}{r}\mathrm{Fe}-\% \\
\mathrm{~S}\end{array}$ & $\begin{array}{r}M g-\% \\
S\end{array}$ & $\begin{array}{r}\mathrm{Ca}-\% \\
\mathrm{~s}\end{array}$ & $\begin{array}{r}T \mathbf{i}-\% \\
\mathbf{S}\end{array}$ & $\begin{array}{r}\text { Mn-ppm } \\
\mathrm{s}\end{array}$ & $\begin{array}{r}\text { Ag-ppm } \\
\mathbf{S}\end{array}$ & $\begin{array}{r}\text { B-ppm } \\
S\end{array}$ & $\begin{array}{r}\text { Ba-ppm } \\
\mathrm{s}\end{array}$ & $\begin{array}{r}\text { Be-ppm } \\
S\end{array}$ \\
\hline 1 & 331216 & $112 \quad 14 \quad 10$ & 15 & 0.7 & 1.0 & 1.0 & 3000 & $<.5$ & 20 & 300 & 2.0 \\
\hline 2 & 331020 & 1121255 & 5 & 2.0 & 2.0 & 1.0 & 2000 & $\mathbf{N}$ & 20 & 700 & 2.0 \\
\hline 3 & $33 \quad 1004$ & 1121332 & 10 & 1.5 & 2.0 & 0.7 & 2000 & $\mathbf{N}$ & 20 & 700 & 2.0 \\
\hline 4 & 330931 & 1121220 & 15 & 1.5 & 3.0 & $>1.0$ & 5000 & $\mathbf{N}$ & $<10$ & 500 & 1.5 \\
\hline 5 & 330957 & 1121245 & 20 & 1.5 & 3.0 & $>1.0$ & 5000 & N & 20 & 500 & 1.5 \\
\hline 6 & $\begin{array}{lll}33 & 13 & 10\end{array}$ & 1121207 & 5 & 3.0 & 3.0 & 0.3 & 1500 & $\mathbf{N}$ & $<10$ & 700 & 1.5 \\
\hline 7 & 331331 & 1121206 & 15 & 1.5 & 2.0 & 1.0 & 1000 & $N$ & 10 & 500 & 1.5 \\
\hline 8 & $3314 \quad 47$ & 1121222 & 15 & 5.0 & 5.0 & 1.0 & 5000 & $\mathbf{N}$ & 10 & 1000 & 1.5 \\
\hline 9 & $3314 \quad 45$ & 1121326 & 10 & 2.0 & 3.0 & 0.7 & 2000 & $\mathbf{N}$ & $<10$ & 500 & 1.5 \\
\hline 10 & $33 \quad 1202$ & 1121343 & 15 & 1.5 & 2.0 & 1.0 & 3000 & $\mathbf{N}$ & $<10$ & 500 & 2.0 \\
\hline 11 & 331140 & 1121337 & 10 & 1.5 & 2.0 & 0.5 & 3000 & $\mathbf{N}$ & 10 & 500 & 2.0 \\
\hline 12 & 331257 & 1121335 & 10 & 1.0 & 2.0 & 0.7 & 3000 & $\mathbf{N}$ & 10 & 500 & 2.0 \\
\hline 13 & 331257 & 1121331 & 10 & 2.0 & 3.0 & 0.7 & 2000 & $\mathbf{N}$ & $<10$ & 500 & 2.0 \\
\hline 14 & 331133 & 1121217 & 10 & 1.5 & 2.0 & 0.5 & 1000 & $\mathbf{N}$ & 10 & 500 & $2: 0$ \\
\hline 15 & 331057 & 1121317 & 15 & 1.5 & 2.0 & 1.0 & 2000 & $\mathbf{N}$ & 10 & 500 & 1.5 \\
\hline 16 & 331235 & 1121504 & 10 & 3.0 & 3.0 & 1.0 & 2000 & $\mathbf{N}$ & 10 & 500 & 1.0 \\
\hline 17 & $33 \quad 1232$ & 1121447 & 10 & 2.0 & 2.0 & 0.7 & 1500 & N & 20 & 700 & 2.0 \\
\hline 18 & 331235 & $112 \quad 15 \quad 38$ & 15 & 2.0 & 3.0 & 0.7 & 2000 & $\mathbf{N}$ & 10 & 700 & 1.5 \\
\hline 19 & 331238 & 1121558 & 5 & 1.5 & 2.0 & 0.5 & 1000 & $\mathbf{N}$ & 10 & 300 & 2.0 \\
\hline 20 & 331317 & 1121548 & 7 & 3.0 & 2.0 & 0.7 & 1500 & N & 20 & 500 & 2.0 \\
\hline 21 & $33 \quad 1438$ & 1121540 & 7 & 3.0 & 3.0 & 0.7 & 1500 & $\mathbf{N}$ & 10 & 500 & 1.5 \\
\hline 22 & 331352 & 1121602 & 10 & 2.0 & 3.0 & 1.0 & 1000 & $\mathbf{N}$ & 20 & 700 & 2.0 \\
\hline 23 & $\begin{array}{lll}33 & 14 & 03\end{array}$ & 1121610 & 3 & 2.0 & 1.5 & 0.7 & 1000 & $\mathbf{N}$ & 50 & 700 & 1.5 \\
\hline 24 & 331355 & 1121632 & 5 & 2.0 & 2.0 & 0.7 & 2000 & $\mathbf{N}$ & 20 & 500 & 2.0 \\
\hline 25 & 331359 & 1121707 & 5 & 2.0 & 2.0 & 0.5 & 700 & $\mathbf{N}$ & 30 & 500 & 2.0 \\
\hline 26 & 331420 & 1121734 & 5 & 3.0 & 3.0 & 1.0 & 2000 & $\mathbf{N}$ & 50 & 700 & 1.5 \\
\hline
\end{tabular}


TABLE 3--ANALYSES OF MINUS-80-MESH STREAM SEDIMENT SAMPLES FRÖi THE SIERRA ESTRELLA WILDERNESS STUDY AREA, MARICOPA COUNTY, ARIZONA (Continued)

( $N$, not detected; <, detected but below the limit of determination shown; >, determined to be greater than the value shown.)

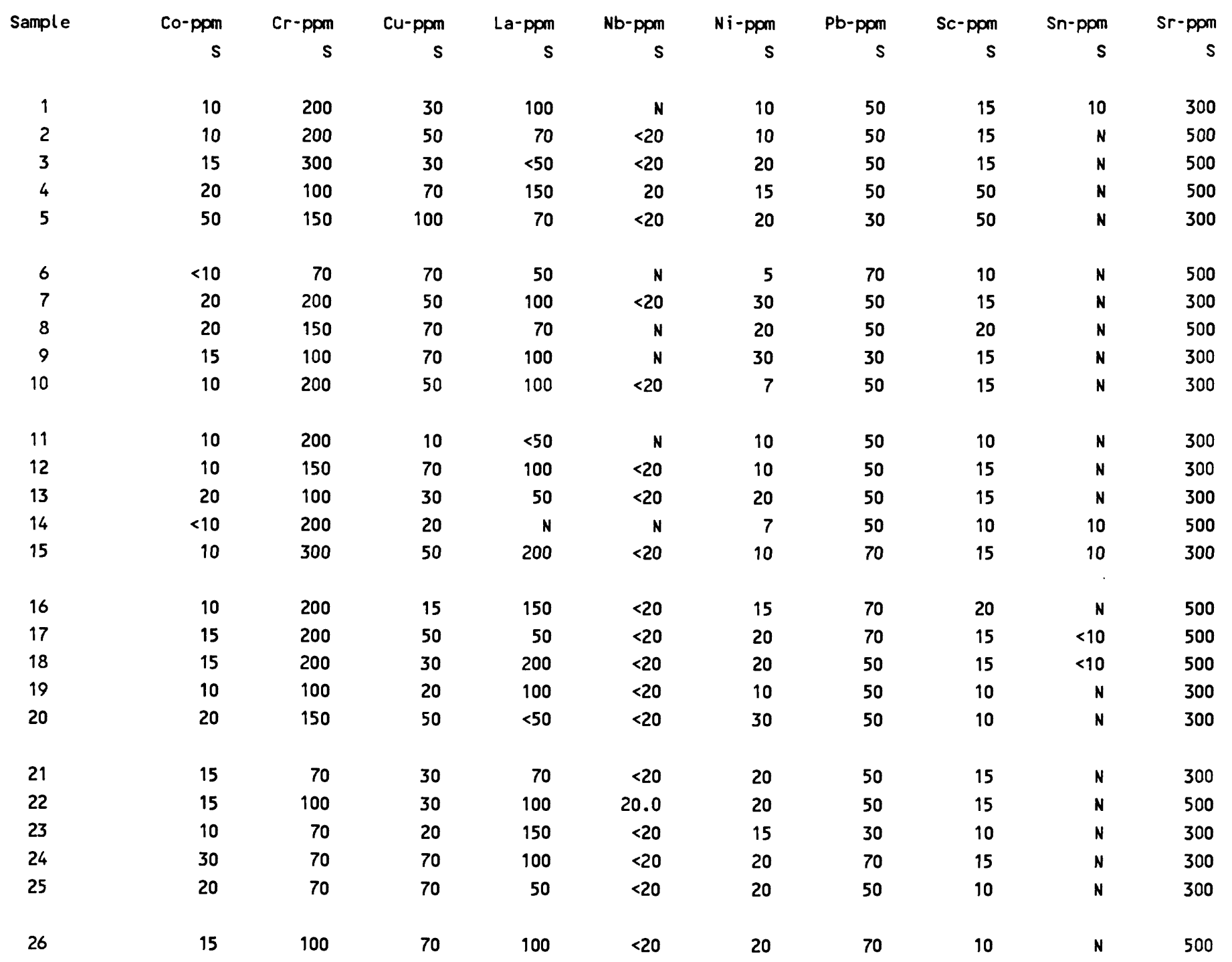


TABLE 3--ANALYSES OF MINUS-80-MESH STREAM SEDIMENT SAMPLES FROM THE SIERRA ESTRELLA WILDERNESS STUDY AREA, MARICOPA COUNTY, ARIZONA (Continued)

( $N$, not detected; <, detected but below the limit of determination shown; >, determined to be greater than the value shown.)

\begin{tabular}{|c|c|c|c|c|c|c|c|c|c|c|c|}
\hline Sample & $\begin{array}{r}v-p p m \\
s\end{array}$ & $\begin{array}{r}Y \text {-ppm } \\
s\end{array}$ & $\begin{array}{r}\mathrm{zr}-\mathrm{ppm} \\
\mathrm{s}\end{array}$ & $\begin{array}{r}\text { Ga-ppm } \\
\text { S }\end{array}$ & $\begin{array}{r}\mathrm{Na}-\% \\
\mathrm{~S}\end{array}$ & $\begin{array}{r}P-\% \\
S\end{array}$ & $\begin{array}{r}\text { Th-ppm } \\
\text { s }\end{array}$ & $\begin{array}{r}\text { As-ppm } \\
\text { ICP }\end{array}$ & $\begin{array}{r}\text { Bi-ppm } \\
\text { ICP }\end{array}$ & $\begin{array}{r}\text { Cd-ppm } \\
\text { ICP }\end{array}$ & $\begin{array}{r}\text { 2n-ppm } \\
\text { ICP }\end{array}$ \\
\hline 1 & 200 & 50 & 200 & 20 & 1.5 & $N$ & $N$ & $<5$ & $<2$ & 0.5 & 21 \\
\hline 2 & 200 & 100 & 200 & 20 & 2.0 & $<0.2$ & $N$ & $<5$ & $<2$ & 0.5 & 36 \\
\hline 3 & 200 & 200 & 150 & 20 & 2.0 & $<0.2$ & $N$ & $<5$ & $<2$ & 0.6 & 33 \\
\hline 4 & 200 & 150 & 1000 & 20 & 1.5 & 0.5 & $N$ & $<5$ & 3 & 0.9 & 33 \\
\hline 5 & 200 & 150 & 1000 & 30 & 1.5 & 0.2 & $N$ & $<5$ & 2 & 1.0 & 32 \\
\hline 6 & 100 & 150 & 150 & 50 & 3.0 & $<0.2$ & $N$ & $<5$ & $<2$ & 0.2 & 51 \\
\hline 7 & 200 & 50 & 700 & 20 & 2.0 & $<0.2$ & $N$ & $<5$ & $<2$ & 0.4 & 33 \\
\hline 8 & 500 & 50 & 200 & 20 & 3.0 & $<0.2$ & $N$ & 5 & $<2$ & 0.5 & 36 \\
\hline 9 & 200 & 100 & 200 & 15 & 1.5 & 0.2 & $N$ & $<5$ & $<2$ & 0.4 & 33 \\
\hline 10 & 300 & 100 & 500 & 10 & 1.5 & $<0.2$ & $N$ & $<5$ & $<2$ & 0.5 & 27 \\
\hline 11 & 150 & 20 & 100 & 20 & 2.0 & $<0.2$ & $N$ & $<5$ & 2 & 0.5 & 25 \\
\hline 12 & 150 & 200 & 700 & 20 & 1.5 & $<0.2$ & $N$ & $<5$ & $<2$ & 0.4 & 27 \\
\hline 13 & 200 & 30 & 200 & 30 & 2.0 & $<0.2$ & $N$ & $<5$ & $<2$ & 0.5 & 31 \\
\hline 14 & 150 & 50 & 150 & 20 & 1.5 & $<0.2$ & $N$ & $<5$ & 3 & 0.4 & 23 \\
\hline 15 & 200 & 50 & 700 & 30 & 1.5 & $<0.2$ & $\mathbf{N}$ & $<5$ & $<2$ & 0.3 & 25 \\
\hline 16 & 150 & 50 & 200 & 30 & 2.0 & $N$ & $N$ & $<5$ & $<2$ & 0.4 & 35 \\
\hline 17 & 200 & 50 & 200 & 30 & 2.0 & $<0.2$ & $N$ & $<5$ & 3 & 0.5 & 40 \\
\hline 18 & 200 & 200 & 500 & 30 & 1.5 & $<0.2$ & 100 & $<5$ & $<2$ & 0.5 & 30 \\
\hline 19 & 100 & 100 & 700 & 20 & 1.5 & $<0.2$ & $N$ & $<5$ & $<2$ & 0.5 & 33 \\
\hline 20 & 150 & 100 & 300 & 20 & 1.5 & 0.2 & $N$ & $<5$ & $<2$ & 0.3 & 34 \\
\hline 21 & 150 & 70 & 700 & 30 & 2.0 & 0.2 & $N$ & $<5$ & $<2$ & 0.3 & 31 \\
\hline 22 & 150 & 70 & 1000 & 20 & 2.0 & 0.2 & $N$ & $<5$ & $<2$ & 0.3 & 23 \\
\hline 23 & 100 & 30 & 700 & 15 & 1.5 & $<0.2$ & $N$ & $<5$ & $<2$ & 0.3 & 31 \\
\hline 24 & 100 & 50 & 500 & 30 & 1.5 & 0.2 & $N$ & $<5$ & $<2$ & 0.3 & 33 \\
\hline 25 & 100 & 70 & 200 & 20 & 1.5 & $<0.2$ & $\mathbf{N}$ & $<5$ & $<2$ & 0.3 & 38 \\
\hline 26 & 150 & 70 & 700 & 30 & 1.5 & 0.2 & $\mathbf{N}$ & $<5$ & $<2$ & 0.3 & 35 \\
\hline
\end{tabular}


TABLE 4--ANALYSES OF NONMAGNETIC HEAVY-MINERAL COMCENTRATE SAMPLES FROM THE SIERRA ESTRELLA WILDERNESS STUDY AREA,

MARICOPA COUNTY, ARIZONA

( $N$, not detected; <, detected but below the limit of determination shown; >, determined to be greater than the value shown.)

\begin{tabular}{|c|c|c|c|c|c|c|c|c|c|c|c|c|c|}
\hline Sample & Lat itude & Longi tude & $\mathrm{Ca}-\%$ & $\mathrm{Fe}-\%$ & $M g-\%$ & $\mathrm{Na}-\%$ & P-\% & $T \mathbf{i}-\%$ & B-ppm & Ba-ppm & Be-ppm & Co-ppm & $\mathrm{Cr}-\mathrm{ppm}$ \\
\hline & & & $s$ & $s$ & $\mathbf{S}$ & $s$ & s & $\mathbf{S}$ & $\mathbf{s}$ & s & $s$ & $S$ & s \\
\hline 1 & 331216 & $112 \quad 14 \quad 10$ & 7 & 1.0 & 0.50 & 1.5 & 3 & 1.5 & $<20$ & 300 & $\mathbf{N}$ & $\mathrm{N}$ & 50 \\
\hline 2 & $\begin{array}{lll}33 & 10 & 20\end{array}$ & 1121255 & 20 & 0.7 & 0.30 & $<0.5$ & 15 & 2.0 & $N$ & 150 & $\mathbf{N}$ & 50 & 70 \\
\hline 3 & $\begin{array}{lll}33 & 10 & 04\end{array}$ & 1121332 & 7 & 0.7 & 0.30 & 1.5 & 3 & 1.5 & $N$ & 500 & $\mathbf{N}$ & $N$ & 50 \\
\hline 4 & 330931 & 1121220 & 30 & 0.3 & 0.15 & 0.7 & 20 & 2.0 & $N$ & 100 & $N$ & $N$ & $<20$ \\
\hline 5 & 330957 & 1121245 & 15 & 0.3 & 0.15 & 0.7 & 15 & 2.0 & $\mathrm{~N}$ & 300 & N & $N$ & $<20$ \\
\hline 6 & $\begin{array}{lll}33 & 13 & 10\end{array}$ & $112 \quad 1207$ & 30 & 0.7 & 1.00 & $N$ & 20 & 2.0 & 20 & 150 & $\mathbf{N}$ & $N$ & 20 \\
\hline 7 & $3313 \quad 31$ & 1121206 & 7 & 1.0 & 1.00 & 1.0 & 7 & 2.0 & $<20$ & 200 & $N$ & $N$ & 70 \\
\hline 8 & $33 \quad 14 \quad 47$ & $112 \quad 12 \quad 22$ & 15 & 0.7 & 0.70 & 1.0 & 7 & 1.5 & $N$ & 200 & $N$ & $\mathrm{~N}$ & 50 \\
\hline 9 & $33 \quad 14 \quad 45$ & 1121326 & 15 & 1.0 & 1.50 & 0.7 & 10 & $>2.0$ & $N$ & 150 & $N$ & $N$ & 50 \\
\hline 10 & $33 \quad 1202$ & $11213 \quad 43$ & 15 & 0.7 & 0.30 & 1.5 & 7 & 2.0 & $\mathrm{~N}$ & 200 & $<2$ & $N$ & 30 \\
\hline 11 & 331140 & $112 \quad 13 \quad 37$ & 20 & 1.5 & 0.30 & 0.7 & 15 & 1.5 & 20 & 150 & 3 & $N$ & 70 \\
\hline 12 & $33 \quad 1257$ & 1121335 & 30 & 0.7 & 0.30 & 1.5 & 15 & 2.0 & $\mathbf{N}$ & 200 & $<2$ & $N$ & 30 \\
\hline 13 & 331257 & 1121331 & 20 & 1.5 & 0.30 & 1.5 & 15 & 1.0 & $N$ & 150 & $<2$ & $N$ & 50 \\
\hline 14 & 331133 & 1121217 & 7 & 2.0 & 0.50 & 2.0 & 3 & 1.5 & 30 & 300 & $<2$ & $\mathrm{~N}$ & 70 \\
\hline 15 & 331057 & 1121317 & 15 & 0.7 & 0.30 & 0.7 & 7 & 2.0 & 50 & 150 & $N$ & $N$ & 50 \\
\hline 16 & $33 \quad 1235$ & 1121504 & 20 & 1.5 & 2.00 & 1.0 & 7 & 2.0 & $<20$ & 150 & $<2$ & $N$ & 30 \\
\hline 17 & $\begin{array}{lll}33 & 12 & 32\end{array}$ & $112 \quad 14 \quad 47$ & 10 & 1.5 & 0.50 & 2.0 & 7 & $>2.0$ & 20 & 300 & $N$ & $N$ & 70 \\
\hline 18 & 331235 & $112 \quad 1538$ & 15 & 1.5 & 1.00 & $<0.5$ & 7 & 2.0 & $N$ & 200 & $N$ & $N$ & 20 \\
\hline 19 & 331238 & $112 \quad 1558$ & 15 & 1.5 & 1.00 & $\mathbf{N}$ & 7 & $>2.0$ & $N$ & 150 & $N$ & $\mathbf{N}$ & 30 \\
\hline 20 & $\begin{array}{lll}33 & 13 & 17\end{array}$ & 1121548 & 7 & 0.7 & 0.50 & 1.5 & 7 & $>2.0$ & $N$ & 200 & $N$ & $\mathbf{N}$ & 30 \\
\hline 21 & $\begin{array}{lll}33 & 14 & 38\end{array}$ & 1121540 & 15 & 0.5 & 0.20 & $\mathbf{N}$ & 10 & $>2.0$ & $N$ & 50 & $N$ & $N$ & 30 \\
\hline 22 & $\begin{array}{lll}33 & 13 & 52\end{array}$ & $112 \quad 16 \quad 02$ & 15 & 0.5 & 0.30 & $N$ & 10 & $>2.0$ & $N$ & 100 & $N$ & $N$ & 50 \\
\hline 23 & $\begin{array}{lll}33 & 14 & 03\end{array}$ & 1121610 & 15 & 0.3 & 0.15 & $\mathbf{N}$ & 10 & $>2.0$ & $\mathrm{~N}$ & 100 & $N$ & $N$ & 30 \\
\hline 24 & 331355 & 1121632 & 15 & 0.3 & 0.20 & $\mathbf{N}$ & 10 & $>2.0$ & $\mathbf{N}$ & 700 & $\mathbf{N}$ & $N$ & 50 \\
\hline 25 & 331359 & $112 \quad 1707$ & 15 & 0.5 & 0.50 & $<0.5$ & 7 & $>2.0$ & $\mathbf{N}$ & 150 & $\mathbf{N}$ & $N$ & 100 \\
\hline 26 & 331420 & 1121734 & 15 & 0.5 & 0.30 & $<0.5$ & 7 & $>2.0$ & $N$ & 200 & $N$ & $N$ & 70 \\
\hline
\end{tabular}


TABLE 4--ANALYSES OF NONMAGNETIC HEAVY-MINERAL COMCENTRATE SAMPLES :ROM THE SIERRA ESTRELLA WILDERNESS STUDY AREA, MARICOPA COUNTY, ARIZONA (Continued)

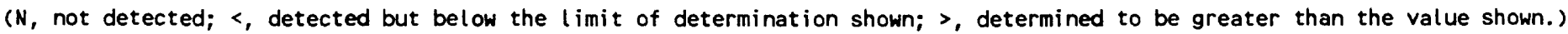

\begin{tabular}{|c|c|c|c|c|c|c|c|c|c|c|c|c|c|}
\hline Sample & Ga-ppm & La-ppm & Mn-ppm & Mo-ppm & Nb-ppm & Pb-ppm & Sc-ppm & Sn-ppm & Sr-ppm & Th-ppm & $v$-ppm & $W$-ppm & $Y-p p m$ \\
\hline & $\mathbf{S}$ & s & s & s & $\mathbf{s}$ & $\mathbf{s}$ & $s$ & $s$ & $\mathbf{s}$ & s & $\mathbf{s}$ & $\mathbf{s}$ & s \\
\hline 1 & 20 & $<100$ & 300 & $\mathbf{N}$ & 50 & 30 & 20 & $\mathbf{N}$ & $N$ & $N$ & 150 & $<50$ & 300 \\
\hline 2 & 15 & $<100$ & 700 & 20 & 50 & 100 & 20 & 200 & $\mathbf{N}$ & $N$ & 150 & 500 & 500 \\
\hline 3 & 15 & $<100$ & 300 & 70 & $<50$ & 20 & 20 & $\mathbf{N}$ & $N$ & $N$ & 70 & 300 & 150 \\
\hline 4 & $<10$ & $<100$ & 300 & $N$ & $<50$ & 30 & 70 & $N$ & $N$ & $N$ & 70 & $\mathbf{N}$ & 700 \\
\hline 5 & 10 & N & 300 & $\mathbf{N}$ & $<50$ & 20 & 50 & $N$ & $N$ & $N$ & 70 & $N$ & 700 \\
\hline 6 & $<10$ & $<100$ & 500 & 15 & 70 & 30 & 15 & $<20$ & $N$ & $N$ & 50 & $N$ & 1000 \\
\hline 7 & 15 & $<100$ & 700 & 300 & 50 & 30 & 10 & $N$ & $N$ & $N$ & 70 & 150 & 300 \\
\hline 8 & 10 & 100 & 300 & 100 & $<50$ & 50 & 20 & $N$ & $N$ & $\mathbf{N}$ & 70 & 1000 & 300 \\
\hline 9 & 20 & $<100$ & 700 & 200 & 100 & 50 & 15 & 20 & $N$ & $\mathbf{N}$ & 150 & 700 & 700 \\
\hline 10 & 10 & $<100$ & 500 & 30 & 70 & 30 & 20 & $N$ & $N$ & $N$ & 100 & 300 & 300 \\
\hline 11 & 30 & $<100$ & 700 & $N$ & 50 & 30 & 15 & $N$ & $N$ & $N$ & 100 & $N$ & 500 \\
\hline 12 & 15 & $<100$ & 1000 & $\mathbf{N}$ & 70 & 30 & 15 & $\mathbf{N}$ & $\mathbf{N}$ & $N$ & 100 & $N$ & 500 \\
\hline 13 & 20 & $<100$ & 1000 & $\mathbf{N}$ & 50 & 30 & 15 & $\mathbf{N}$ & $N$ & $N$ & 100 & $N$ & 500 \\
\hline 14 & 50 & 100 & 500 & $N$ & 50 & 50 & 20 & $\mathbf{N}$ & $N$ & $N$ & 100 & $N$ & 300 \\
\hline 15 & 10 & $<100$ & 300 & $N$ & 50 & 70 & 50 & $N$ & $N$ & $N$ & 100 & 300 & 300 \\
\hline 16 & 20 & $<100$ & 1500 & $N$ & 70 & 30 & 10 & $N$ & $<200$ & $\mathbf{N}$ & 150 & $N$ & 500 \\
\hline 17 & 30 & 100 & 500 & 30 & 70 & 70 & 15 & $\mathbf{N}$ & 200 & $N$ & 200 & 300 & 500 \\
\hline 18 & 15 & $<100$ & 1000 & $<10$ & 70 & 70 & 15 & $N$ & $\mathbf{N}$ & $N$ & 150 & 300 & 500 \\
\hline 19 & 20 & 100 & 1000 & 20 & 150 & 100 & 15 & 20 & $\mathbf{N}$ & $N$ & 200 & $N$ & 700 \\
\hline 20 & 10 & $<100$ & 300 & $<10$ & 100 & 30 & $<10$ & $\mathbf{N}$ & $\mathbf{N}$ & $N$ & 150 & 300 & 500 \\
\hline 21 & $\mathbf{N}$ & 200 & 500 & 30 & 150 & 50 & 15 & 70 & $N$ & $N$ & 200 & $N$ & 1000 \\
\hline 22 & $<10$ & 200 & 700 & 30 & 150 & 70 & 15 & 70 & $N$ & $N$ & 200 & $N$ & 1500 \\
\hline 23 & $<10$ & 150 & 300 & $<10$ & 70 & 70 & 30 & 20 & $N$ & $N$ & 200 & $N$ & 1000 \\
\hline 24 & $<10$ & 150 & 300 & 30 & 150 & 50 & 30 & 70 & $N$ & $N$ & 200 & $N$ & 1000 \\
\hline 25 & $<10$ & 200 & 300 & 30 & 150 & 100 & 30 & 70 & $N$ & 200 & 200 & $N$ & 1000 \\
\hline 26 & $<10$ & 200 & 500 & 30 & 200 & 70 & 50 & 70 & $N$ & $<200$ & 200 & 70 & 1000 \\
\hline
\end{tabular}


TABLE 5--ANALYSES OF ROCK SAMPLES FROM THE SIERRA ESTRELLA WILDERNESS STUDY AREA, MARICOPA COUNTY, ARIZONA.

( $N$, not detected; <, detected but below the limit of determination shown; >, determined to be greater than the value shown.)

\begin{tabular}{|c|c|c|c|c|c|c|c|c|c|c|c|c|c|}
\hline Sample & Latitude & Longi tude & $\begin{array}{r}\mathrm{Fe}-\mathrm{X} \\
\mathrm{S}\end{array}$ & $\begin{array}{r}M g-x \\
S\end{array}$ & $\begin{array}{r}\mathrm{Ca}-\mathrm{x} \\
\mathrm{s}\end{array}$ & $\begin{array}{r}T i-x \\
S\end{array}$ & $\begin{array}{r}\text { Mn-ppm } \\
S\end{array}$ & $\begin{array}{r}\text { Ag-ppm } \\
S\end{array}$ & $\begin{array}{r}\text { B-ppm } \\
S\end{array}$ & $\begin{array}{r}\text { Ba-ppm } \\
s\end{array}$ & $\begin{array}{r}\text { Be-ppm } \\
S\end{array}$ & $\begin{array}{r}8 i-p p m \\
s\end{array}$ & $\begin{array}{r}\text { Co-ppm } \\
\text { s }\end{array}$ \\
\hline SEO1R & $\begin{array}{lll}33 & 12 & 16\end{array}$ & $11214 \quad 10$ & 20.0 & 0.05 & $<.05$ & 1.000 & 500 & $N$ & $N$ & 500 & $N$ & $N$ & 10 \\
\hline SE02R & 331020 & 1121255 & 5.0 & 0.50 & 1.00 & 0.300 & 700 & $N$ & 10 & 500 & $<1$ & $N$ & 10 \\
\hline SE06R & 331310 & $112 \quad 1207$ & 0.5 & 0.03 & 0.50 & 0.005 & 200 & $<0.5$ & 10 & 700 & 1.0 & $N$ & N \\
\hline SE 10R & $\begin{array}{lll}33 & 12 & 02\end{array}$ & 1121343 & 5.0 & 0.07 & 0.50 & 0.100 & 1000 & 2 & $<10$ & 200 & 1.0 & 20 & $<10$ \\
\hline SE 16R & $\begin{array}{lll}33 & 12 & 27\end{array}$ & $112 \quad 1524$ & 1.0 & 0.20 & 0.30 & 0.200 & 500 & $N$ & 10 & 500 & $<1$ & $N$ & $<10$ \\
\hline
\end{tabular}

\begin{tabular}{|c|c|c|c|c|c|c|c|c|c|c|c|c|c|}
\hline Sample & Cr-ppm & Cu-ppm & La-ppm & $N i-p p m$ & $P b-p p m$ & Sc-ppm & Sn-ppm & Sr-ppm & v-ppm & $Y$-ppon & $2 r-p p m$ & Ga-ppm & $\mathrm{Na}-\mathrm{X}$ \\
\hline & $\mathbf{s}$ & $\mathbf{s}$ & $\mathbf{s}$ & $\mathbf{s}$ & $\mathbf{S}$ & $\mathbf{s}$ & $\mathbf{S}$ & $\mathbf{S}$ & $\mathbf{S}$ & $\mathbf{s}$ & $\mathbf{s}$ & $\mathbf{S}$ & $\mathbf{S}$ \\
\hline SEOIR & $N$ & $<5$ & $N$ & 20 & N & 30 & 30 & $N$ & 70 & $N$ & $<10$ & 20 & 0.2 \\
\hline SE02R & 50 & $<5$ & 50 & 20 & 30 & 10 & N & 500 & 70 & 30 & 70 & 30 & 1.5 \\
\hline SE06R & $N$ & 5 & N & $<5$ & 20 & $<5$ & $N$ & 200 & 10 & $<10$ & $<10$ & 20 & 2.0 \\
\hline SE1OR & 15 & 10000 & 70 & 5 & 30 & 5 & $N$ & 200 & 100 & 15 & 100 & 30 & 1.5 \\
\hline SE16R & $<10$ & 50 & $<50$ & 5 & 30 & 7 & $N$ & 150 & 20 & 15 & 70 & 30 & 2.0 \\
\hline
\end{tabular}

Table 6.--Description of rock samples

$01 R \quad$ Pegmatite

02R Gneiss with epidote veins

06R Foliated biotite granite with accessory fluorite

10R Copper-stained quartz vein in granite

$16 R$ Silicified intrusive 